\title{
Constraints of Small and Medium Food Industry to Take Advantage of Domestic Market Opportunities during the Covid-19 Pandemic
}

\author{
Stefanus Yufra M. Taneo ${ }^{1}$, Sunday Noya ${ }^{2}$, Etsa Astridya Setiyati ${ }^{3}$, and Melany ${ }^{4}$ \\ ${ }^{1}$ Management Study Program, Faculty of Economics and Business, Universitas Ma Chung, \\ Indonesia \\ ${ }^{2}$ Industrial Engineering Study Program, Faculty of Science and Technology, Universitas Ma \\ Chung, Indonesia \\ ${ }^{3}$ Entrepreneurship Program, Bina Nusantara University, Indonesia \\ ${ }^{4}$ English Letters Study Program, Faculty of Language and Art, Universitas Ma Chung, Indonesia \\ ORCID:
}

Stefanus Yufra M. Taneo: http://orcid.org/0000-0003-3769-8652

\section{Abstract}

The small and medium-sized food industry (SMFI) has a great opportunity to meet domestic market demand during the Covid-19 pandemic but there are various obstacles. This paper aims to present the constraints faced by SMFIs, especially concerning raw materials and marketing, in taking advantage of domestic market opportunities, and proposes alternative solutions. The study was conducted on four SMFIs that produce functional food in Malang Regency. Data were collected through in-depth interviews. The results showed that the demand for functional foods such as garlic, ginger, turmeric and fruits increased during the Covid-19 pandemic, which seemed to be related to public awareness about increasing immunity. However, the obstacles faced by SMFIs were the high price of raw materials due to limited supply, and limited marketing because they did not have distribution licenses from BPOM. Information about the process and BPOM's distribution permit requirements was very limited for SMFI managers, and large capital was needed to fulfill the requirements of Good Manufacturing Practices. Therefore, SMFIs should have long-term cooperation with farmers to ensure the availability of raw materials; build networks and maintain cooperation with customers; and utilize credit for MSMEs in the economic recovery program provided by the government to meet the GMP requirements in BPOM's distribution permit. The government should conduct intensive outreach to SMFI managers about the process and requirements for distribution permits from BPOM, credit facilities, and other policies related to economic recovery during the Covid-19 pandemic.

Keywords: Small and medium food industry, domestic market, Covid-19 pandemic, BPOM 


\section{Introduction}

The Corona Virus Disease 2019 (Covid-19) pancemic has a major impact on all parties including the small and medium-sized food industry (SMFI). Small and medium industries refer to micro, small and medium enterprises (MSMEs) that carry out production and then sell their products, while some MSMEs only do reselling. The Ministry of Cooperatives and Small and Medium Enterprises and Cooperatives, reported that as of August 2020 as many as 12 million MSMEs and cooperatives had been affected by Covid-19 (Tribunjogja, 2020). Small and Medium Industries face three challenges (Kompas.com, 2020). The first challenge is difficulty to obtain raw materials. Since the implementation of physical distancing in almost all regions, many MSMEs have experienced difficulties in obtaining raw materials. Physical distancing also disrupted logistical distribution, causing consignments to be ordered or purchased for a long time.

The second challenge is cash flow. Many MSMEs have experienced income decreased due to the absence of customers who have purchased products since physical distancing was implemented. In addition, MSME players also have difficulty obtaining capital loans. Income has decreased, production costs are more expensive, plus the difficulty of access to borrowing capital has disrupted the cash flow of MSMEs. This challenge was also found by Raflis, Ishak, \& Jusoh (2020) on SMFIs in Malaysia.

The third challenge is that demand has decreased significantly. Market uncertainty affects the demand for goods sold by MSMEs. Purchases are carried out online while only about 13 percent of the 64 million MSMEs are connected to the digital ecosystem, the rest carry out all business activities through physical interactions (Brodjonegoro, 2020). Moreover, since there was a pandemic, consumer needs have changed. Today many people need health products such as hand sanitizers and masks more than other needs. Meanwhile, the Minister of Cooperatives and SMEs said that the current situation of MSMEs was very different compared to the crisis in 1998. In 1998, MSMEs could become the backbone of the economy; on the other hand, currently MSMEs are the most affected both in terms of demand and in terms of raw material availability.

Behind the above challenges, there is an opportunity for SMFIs to meet domestic market as an import substitute during Covid-19 because many countries have implemented lockdowns to prevent the spread of the virus. According to the Special Staff of the Minister of Cooperatives and SMEs, it is hoped that SMFIs can supply goods that are empty due to imports that have been stopped from countries that have locked down, especially from China (Liputan6, 2020). The Minister of Cooperatives and SMEs wants 
MSME products to dominate the domestic market and penetrate the export market (Avisena, 2019).

In fact, MSMEs have not been able to meet the needs of the domestic market. There are at least two major obstacles faced by SMFIs in fulfilling the domestic market, namely weak supply chain management (Ariani \& Dwiyanto, 2013; Kurniawan \& Kusumawardhani, 2017; Raflis et al., 2020), even the global supply chain (Bouey, 2020) and not having distribution permits (BPOM RI, 2017; Yulianti \& Mustarichie, 2018). Supply chain management is related to the management of all related parties, from suppliers, manufacturers, distributors, retailers, and customers in creating cheap, quality, and fast products (Agus, 2015). The research of Ariani \& Dwiyanto (2013) on the effect of supply chain management on the performance of processed food MSMEs typical of Padang City, found that long-term relationships have a positive effect on supply chain management performance.

The modern retail market network is very strong, reaching almost all regions of Indonesia. Martadisastra (2017) found that supplier performance in modern retail supply chains is strongly influenced by competitive conditions. The tighter the level of competition, the tighter the performance of suppliers in the modern retail supply chain tends to be tighter and has the potential to increase supplier performance, however, the influence of competition in its implementation is dominated by modern retailers which are expansively developing outlet networks and tend to meet consumer expectations, resulting in increased concentration and bargaining power and the purchasing power of modern retail. On the other hand, suppliers are only focused on fighting for market access, so the bargaining power of suppliers is very weak.

Apart from supply chain management constraints, Law No. 36/2009 states that "Food and beverages can only be distributed after obtaining a distribution permit in accordance with the provisions of laws and regulations". The results of monitoring by BPOM RI (2017) for the period January to June 2017 on 4,333 food distribution facilities with the result that 1,471 (33.95\%) facilities did not meet the requirements, because one of them was selling food without a distribution permit $(3,760,060$ pcs).

Distribution permits are carried out by registering processed food products with BPOM (Badan Pengawas Obat dan Makanan/The Agency of Drug and Food Control). Based on Article 15 paragraph 2 BPOM 26/2018 and Attachment I BPOM Regulation $27 / 2017$, one of the requirements is "Document of production facility audit results, risk management program charter, or Good Manufacturing Practices (GMP) certificate". GMP is a production method that takes into account the food safety aspects, among others by (i) preventing the contamination of processed food by biological, chemical and other 
contaminants, (ii) killing or preventing pathogenic microorganisms from living, and (iii) controlling the production process.

The scope of the GMP guidelines are: (i) location, (ii) buildings, (iii) sanitation facilities, (iv) machinery and equipment, (v) materials, (vi) process control, (vii) final products, (vii) laboratories, (ix) employees, (x) packers, (xi) product labels and descriptions, (xii) storage, (xiii) maintenance and sanitation programs, (xiv) transportation, (xv) documentation and record keeping, (xvi) training, (xvii) product recall, (xviii) implementation of guidelines. GMP is a requirement for HACCP (Hazard Analysis Critical Point) implementation.

The role of MSMEs, especially SMFI is very important in Indonesia's economic recovery because of its contribution to employment (97\%) and gross domestic product/GDP (57\%). For this reason, increasing the capacity of SMFIs in accessing the domestic market is very important. Therefore, this paper aims to present the constraints faced by SMFIs, especially raw materials and marketing in taking advantage of domestic market opportunities during the Covid-19 pandemic period and to provide alternative solutions.

\section{Method}

Data were collected from four SMFls in Malang Regency, namely (i) Qinar, producing four variants of fruit drink products, (ii) Doea D, producing traditional kencur rice drink, (iii) Alfania, producing herbal drinks, and (4) N'Up, produces black onion snacks with several variants made from garlic and several types of drinks made from local flower plants.According to the classification of the Indonesian Central Statistics Agency (BPS), small industry employs less than 20 people and medium industry employs 20 to 100 people. This criterion is more practical than the criteria according to Law number 20 of 2008 concerning Micro, Small and Medium Enterprises (MSMEs) based on net worth and annual sales results.Qinar is a medium-sized industry, while the other three are small-scale industries. Description of the SMFIs studied are presented in Table 1.

Notes:

PIRT: Pangan Industri Rumah Tangga (Licence for home industry food)

NIB: Nomor Induk Berusaha (business identification number)

BPOM: Badan Pengawas Obat dan Makanan (National Agency for Drug and Food Control)

The first SMFI (Qinar), four of its product variants, have obtained distribution permits from BPOM. The second SMFI (Doea D), has been in the process of obtaining a distribution permit from BPOM through the East Java Provincial Government program: 
TABLE 1: Profile of small and medium food industry studied

\begin{tabular}{|c|c|c|c|c|}
\hline & Qinar. & Deea D & Alfania & N'UR \\
\hline $\begin{array}{l}\text { The manager } \\
\text { name }\end{array}$ & Mrs. Henny & Mrs. Muii & Mrs. Maslukchah & Mrs. Neneng \\
\hline $\begin{array}{l}\text { Addres/place of } \\
\text { business }\end{array}$ & $\begin{array}{l}\text { Desa Talok, } \\
\text { Kecamatan Turen, } \\
\text { Kaupaten Malang }\end{array}$ & $\begin{array}{l}\text { Desa Pandesari. } \\
\text { Kecamatan } \\
\text { Puign, Kabupaten } \\
\text { Malang }\end{array}$ & $\begin{array}{l}\text { Desa Gading, } \\
\text { Kecamatan } \\
\text { Buluawang } \\
\text { Kaburaten. } \\
\text { Malang }\end{array}$ & $\begin{array}{l}\text { Desa } \\
\text { Sumberselcar. } \\
\text { Kecamatan Dau, } \\
\text { Kaburaten } \\
\text { Malang } \\
\end{array}$ \\
\hline Year of operation & 2019 & 2016 & 1995 & 2017 \\
\hline Form of bussiness & $\mathrm{CV}$ & Individual & Individual & Individual \\
\hline Product(s) & $\begin{array}{l}\text { Passion fruit, } \\
\text { dragon fruit, apple, } \\
\text { apple \& lychee } \\
\text { flavored drinks }\end{array}$ & $\begin{array}{l}\text { Traditional drink } \\
\text { "beras bencur" }\end{array}$ & $\begin{array}{l}\text { Herbal dinns } \\
\text { with } 12 \text { product } \\
\text { yarians } \\
\text { (eg.ginger } \\
\text { turmeric) }\end{array}$ & $\begin{array}{l}\text { Black garlic and } \\
\text { natural food, and } \\
\text { various drinks } \\
\text { made from local } \\
\text { flowers }\end{array}$ \\
\hline Number of labor & 39 person & 2 person & 2 person & 6 person \\
\hline $\begin{array}{l}\text { Legal document } \\
\text { that have been } \\
\text { owned }\end{array}$ & $\begin{array}{l}\text { - PIRT } \\
\text { - Halal Certificat } \\
\text { - NIB } \\
\text { - Distribution } \\
\text { permit number } \\
\text { from BPOM }\end{array}$ & $\begin{array}{l}\text { - PIRT } \\
\text { - Halal Certificat } \\
\text { - NIB } \\
\text { - Ongoing } \\
\text { process to get } \\
\text { distribution } \\
\text { permit from } \\
\end{array}$ & $\begin{array}{l}\text { - PIRT } \\
\text { - Halal } \\
\text { Certificate } \\
\text { - NIB }\end{array}$ & $\begin{array}{l}\text { - PIRT } \\
\text { - Halal Certificate } \\
\text { - NIB }\end{array}$ \\
\hline Marketing channel & $\begin{array}{l}\text { - Online and } \\
\text { offline } \\
\text { - Supply to the } \\
\text { modern ritel } \\
\text { market }\end{array}$ & $\begin{array}{l}\text { - Online (helped } \\
\text { by her } \\
\text { children) and } \\
\text { offline } \\
\text { - Through } \\
\text { personal } \\
\text { relationhsin }\end{array}$ & $\begin{array}{l}\text { - Online (helped } \\
\text { by her } \\
\text { children) and } \\
\text { offline } \\
\text { - Through } \\
\text { personal } \\
\text { relationship }\end{array}$ & $\begin{array}{l}\text { - Online (helped } \\
\text { by her children) } \\
\text { and offline } \\
\text { - Through } \\
\text { personal } \\
\text { relationship }\end{array}$ \\
\hline
\end{tabular}

Gempur (Movement to Guard People's Business Growth) East Java. The third and fourth SMFIs have the potential to develop and the perpetrators have the desire to obtain a distribution permit from BPOM so that marketing can be broader, but they face several obstacles.

Many SMFIs have experienced problems in obtaining distribution permits. Research conducted on the three conditions of SMFIs, namely those that have successfully obtained a distribution permit, are in the process of revising requirements, and those who have not submitted registration, are expected to provide information about the constraints faced and then proposed alternative solutions.

\section{Results}

The performance and constraints faced by the four SMFIs studied are presented in Table 2 below. 
TABLE 2: Performace and constraints faced by the four SMFIs studied

\begin{tabular}{|c|c|c|c|c|}
\hline $\begin{array}{l}\text { Performance and } \\
\text { constraints }\end{array}$ & CV. Qinar & Doea D & Alfania & N'Up \\
\hline $\begin{array}{l}\text { Sales: } \\
\text { i. The beginning } \\
\text { Covid-19 (Mart- } \\
\text { April) }\end{array}$ & $\begin{array}{l}\text { Decreade by about } \\
40 \%, 6000 \text { carton } \\
\text { pack from usual } \\
\text { around } 10,000 \\
\text { carton pack }\end{array}$ & $\begin{array}{l}\text { Decreased by } 90 \% \text {, } \\
\text { from average } 2000 \\
\text { boxes to } 20 \text { boxes } \\
\text { per month }\end{array}$ & $\begin{array}{l}\text { - Increased more } \\
\text { than } 100 \%\end{array}$ & $\begin{array}{l}\text { Decreased by } \\
70 \%\end{array}$ \\
\hline $\begin{array}{l}\text { ii. May to } \\
\text { September }\end{array}$ & $\begin{array}{l}\text { Increase and reach } \\
24.000 \text { carton pack }\end{array}$ & $\begin{array}{l}\text { Depending on the } \\
\text { order, average } 20 \\
\text { boxes per month }\end{array}$ & $\begin{array}{l}\text { - Decreased } \\
\text { compare to the } \\
\text { begiining of } \\
\text { Covid-19 due to } \\
\text { shortage of raw } \\
\text { material }\end{array}$ & $\begin{array}{l}\text { Increased and has } \\
\text { recovered as } \\
\text { before Covid-19 }\end{array}$ \\
\hline $\begin{array}{l}\text { iii. After obtaining } \\
\text { a distribution } \\
\text { permit from } \\
\text { BPOM }\end{array}$ & $\begin{array}{l}\text { Sales increase by } \\
\text { around } 400 \% \text { during } \\
\text { Mai-July } 2020\end{array}$ & $\begin{array}{l}\text { Distribution permit is } \\
\text { being revised }\end{array}$ & - & - \\
\hline $\begin{array}{l}\text { Constaints: } \\
\text { - Raw material }\end{array}$ & $\begin{array}{l}\text { There is no problem } \\
\text { because it has } \\
\text { cooperated with } \\
\text { local farmers }\end{array}$ & $\begin{array}{l}\text { Production depends } \\
\text { on demand so that } \\
\text { raw material are met } \\
\text { by local farmers so } \\
\text { far }\end{array}$ & $\begin{array}{l}\text { - The price is } \\
\text { expensive } \\
\text { because it is } \\
\text { shortage } \\
\text { - Production of } \\
\text { partner farmers } \\
\text { does not meet the } \\
\text { needs }\end{array}$ & $\begin{array}{l}\text { - There are } \\
\text { already partners } \\
\text { in Batu Market } \\
\text { - There are no } \\
\text { partners with } \\
\text { farmers }\end{array}$ \\
\hline - Marketing & $\begin{array}{l}\text { - The consignment } \\
\text { system affect cash } \\
\text { flow because money } \\
\text { is received after } 60 \\
\text { days } \\
\text { - } 20 \% \text { return rate }\end{array}$ & $\begin{array}{l}\text { - Limited area } \\
\text { - Highly dependent } \\
\text { on orders }\end{array}$ & $\begin{array}{l}\text { Limited because } \\
\text { they do not have } \\
\text { distribution permit }\end{array}$ & $\begin{array}{l}\text { Limited because } \\
\text { they do not have } \\
\text { distribution permit }\end{array}$ \\
\hline $\begin{array}{l}\text { Contraints in } \\
\text { processing } \\
\text { distribution permit } \\
\text { from BPOM }\end{array}$ & $\begin{array}{l}\text { Laboratory tests } \\
\text { must go to Surabaya }\end{array}$ & $\begin{array}{l}\text { There are no } \\
\text { obstacles because } \\
\text { the government } \\
\text { helps through the } \\
\text { GEMPUR program }\end{array}$ & $\begin{array}{l}\text { Limited } \\
\text { information on: } \\
\text { - Permission } \\
\text { process } \\
\text { - lay out of } \\
\text { production } \\
\text { process } \\
\text { - specification of } \\
\text { production } \\
\text { equipment }\end{array}$ & $\begin{array}{l}\text { - Limited capital } \\
\text { for renovation of } \\
\text { production aly out } \\
\text { according to GMP } \\
\text { - Equipment does } \\
\text { not meet GMP } \\
\text { compliant. } \\
\text { - Equipments are } \\
\text { expensive and } \\
\text { wastefull of } \\
\text { electricity }\end{array}$ \\
\hline $\begin{array}{l}\text { Time required fo } \\
\text { distribution permit } \\
\text { from BPOM }\end{array}$ & 3-4 months & $\begin{array}{l}\text { Takes time. It needs } \\
\text { to be reviesed after } \\
\text { laboratory test }\end{array}$ & - & - \\
\hline $\begin{array}{l}\text { Costs: } \\
\text { i. Registration }\end{array}$ & $\begin{array}{l}\text { Rp } 300,000 \text {. SMFIs } \\
\text { gets } 50 \% \text { discount }\end{array}$ & $\begin{array}{l}\text { It costs nothing } \\
\text { because it is } \\
\text { assisted trough the } \\
\text { GEMPUR program }\end{array}$ & - & - \\
\hline ii. Laboratoria test & $\begin{array}{l}\text { Rp } 4,800,000 \\
\text { (Rp600,000 per } 1 \\
\text { item, for } 8 \text { item) for } \\
\text { one varian product }\end{array}$ & & - & - \\
\hline
\end{tabular}




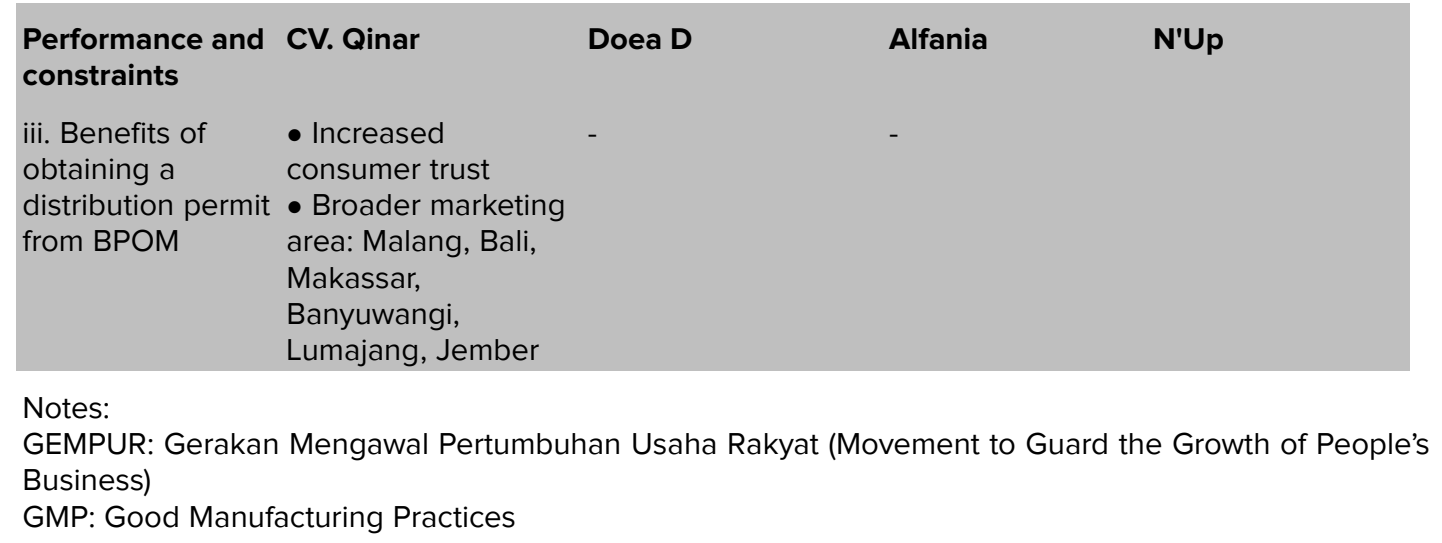

\section{Discussion}

Suppy chain constraint for production-based MSMSs, that is SMFIS, is raw material. If the production is in small quantities, there will be no difficulty in raw materials as experienced by Doea D in the production of the traditional drink "beras kencur" and N'Up in producing black garlic, various snacks made from garlic and drinks from local flower planting. Raw materials can still be met from the production of farmers in areas around the production area. However, when market demand increases significantly, as experienced by Alfania in producing herbs, raw materials do not meet production capacity. As a result, the price of raw materials becomes expensive which in turn will reduce profits because the selling price is difficult to be increased significantly. The cooperation between Doea D, Alfania, and N'Up with farmers in the supply of raw materials is still limited.

This is different from what happened to Qinar, who had no difficulty in getting raw materials to produce drinks flavored with passion fruit, dragon fruit, apple, apple and lychee. The main raw material needed in the greatest amount is passion fruit. The Qinar manager had invested several years earlier by distributing free passion fruit seeds to farmers in the village for planting. Passion fruit production by local farmers is sold to Qinar.

Marketing of Qinar products covers a wider area because it has a distribution license (MD) from BPOM. Consumer trust has increased so that sales have increased significantly, reaching 400\% around May-July 2020. Sales are carried out through retail shops, offices or government and private institutions, as well as direct consumers. The marketing network is quite extensive both online and offline. There are great sales opportunities through distributors. However, the obstacle faced is that the consignment system from large distributors affects cash flow. The value of the product for a single 
product return is IDR 500 million, but the distributor will only make payment after 60 days with a $20 \%$ rate of return on unsold product. Qinar needs to develop a sub-agent strategy in various distribution areas, as is done by SMIs in Malaysia, by using sub-agents in every state (Raflis et al., 2020).

Marketing constraints faced by SMFIs that have not obtained a distribution license (MD) from BPOM are the limited scope of marketing. Marketing is only carried out through personal relationship, through retail shops, and Malang Regency SMI galleries provided by the Malang Regency government. The Malang Regency SMI Communication Forum facilitated by the Industry and Trade Office is one of the places to increase the collaboration between SMFI to overcome supply chain management problems, from the procurement of raw materials to product sales. Sales are also carried out online with the help of the children who are more familiar with digital technology. Managers are the baby boomers and the $X$ generation, so they still need learning and adaptation to the use of information technology. This weakness has been identified by (Afolayan et al., 2015) and Qosasi et al. (2019). Therefore, training on the use of information technology for SMFI managers is important to be done.

Alfania and N'Up products have foreign and domestic market opportunities, but these two SMFIs do not yet have a distribution license (MD) from BPOM. Registration of a distribution permit (MD) to BPOM needs to include the following documents: (i) application letter, (ii) Industrial Registration Certificate/Industrial Business License from the Department of Industry and Trade, (iii) map of location to the factory, (iv) facility layout, (v) production process flow, (vi) results of product testing analysis from an Accredited Laboratory (if any), (vii) list of production equipment and laboratory equipment, (viii) SNI Certificate (for SNI compulsory products), (ix) list of foodstuffs and food additives used (if necessary), (x) Taxpayer Identification Number, (xi) quality guide/standard operational procedure (SOP) (if necessary), and (xii) a contract / license / repacking agreement letter (if the applicant produces production by contract/license/repacking) (BPOM, 2014).

The main obstacles faced by SMFIs are (i) limited information on the licensing process, (ii) production process layout in accordance with BPOM provisions, (iii) production equipment specifications that meet health requirements and are generally expensive and use large amounts of electricity, and (iv) limited capital for SMFls to meet all GMP requirements. Research by Maryati, Syarief, \& Hasbullah (2016) on 30 MSME frozen food in the Jabodetabek area found that the biggest obstacle was complicated permit processing (43.30\%), followed by laboratory tests (16.70\%), expensive (16.70\%), business capital (13.30\%), and industrial business permits (6.70\%). Therefore, $96.7 \%$ did not have a distribution permit, while 3.3\% did not answer, so it can be said that all of them did 
not have a distribution permit. Rose (2011) found that due to financial and resources constraints, SMEs are reluctant to implement GMP before foreseen the benefits. Not fulfilling GMP does not only affect consumer confidence but also on unsatisfactory food hygiene and lacking in sustainability (Hasnan, Aziz, Zulkifli, \& Taip, 2014) and therefore requires government and industry practitioners' intervention (Norsia Hami, Fadhilah Mad Yamin Shafini Mohd Shafie, Mohd Razali Muhamad, 2018)Hami et al., 2018).

SMFI Qinar succeeded in obtaining a domestic distribution license (MD) with a high cost for a SMFIs. The capital required for the building according to the layout and equipment including water distillation is Rp 700 million. The laboratory test costs around $\mathrm{Rp} 4,800,000$ for one product variant. If in the laboratory test there are items that do not meet the requirements, then a retest must be done at a cost of Rp. 600,000 per item. The obstacle Qinar faced was that the test had to be carried out in Surabaya, namely at the BPOM or Surabaya Industrial Research and Standardization Center. The registration fee is Rp 300,000 and there is a 50\% discount for SMEs. The licensing process takes about 4 months for a variety of products. Qinar has successfully obtained distribution permits for four of its product variants.

The Provincial Government of East Java has a GEMPUR program (Movement to Guard the Growth of People's Business) to facilitate and finance a limited number of SME distribution permits. In 2019, there were two Malang Regency SMFIs that received GEMPUR facilities, one of which was Doea $D$ which had registered and had been facilitated in the layout and audit of the production equipment used. It has been more than 6 months that Doea D has not succeeded in obtaining a domestic distribution permit because there are still laboratory and brand test requirements that need to be revised. According to the Surabaya POM Center (BPOM, 2020), the assessment of food production facilities in 2019 of 483 facilities with the result that 262 facilities (53.58\%) met the provisions and 227 (46.42\%) did not meet the requirements, including an assessment of food MSMEs that followed East Java GEMPUR assistance program. Therefore, government facilitation through GEMPUR for SMEs to obtain distribution permits from BPOM still needs to be increased in effectiveness in selecting SMEs that have the potential to meet the specified requirements.

This study shows that the medium-scale food industry (MFI) has a greater capital and is able to qualify for a distribution permit from BPOM to obtain greater market access than the small-scale food industry (SFIs). This study reinforce the findings of Ibrahim, Abdullah, \& Ismail (2016) and Amat \& Ishak (2019), that SMFIs must implement marketing and information technology innovations to survive in an uncertain situation such as Covid-19. 
Based on their research on the impact of Covid-19 in China, Donthu \& Gustafsson, (2020) suggested two business strategies to face the crisis. First, companies that are highly impacted should carry out a collective strategy to build new businesses in collaboration with other companies. Second, companies that were less affected during the Covid-19 crisis can take an alternative approach through a partnership strategy. The company should be open to offers of cooperation with other companies.

\section{Conclusion}

The small and medium-sized food industry (SMFI) has a great opportunity to fill the domestic market during the Covid-19 pandemic, especially functional foods such as garlic, ginger, turmeric traditional drink of beras kencur, and fruits to increase people's immunity. The fact is that SMFIs face problems in procuring raw materials if market demand increases significantly; marketing is still limited because they do not have a domestic distribution permit from BPOM. Information about the process and distribution permit requirements is still very limited for SMFIs manager. In addition, a large amount of capital is needed for SMFI to renovate or build production sites that meet GMP requirements including laboratory tests from accredited institutions that only exist in Surabaya and become expensive if they do not meet the requirements and have to be retested.

In order to take advantage of domestic market opportunities, SMFIs should have long-term cooperation with farmers in their villages to ensure the availability of raw materials, as did by Qinar. SMFIs managers also need to build networks and maintain cooperation with customers. Limited capital to meet the GMP requirements in order to obtain a distribution permit should use credit for MSMEs through the government's economic recovery program. For this reason, the government should collaborate with various parties (for example universities, mass media) to conduct intensive outreach to MSMEs including SMFIs about the process and requirements for distribution permits from BPOM, credit facilities, and other government policies related to economic recovery in during the Covid-19 pandemic.

\section{Funding}

The research was funded by the Ministry of Education and Culture of the Republic of Indonesia in 2019-2020. 


\section{Conflict of Interest}

The authors have no conflict of interest to declare.

\section{References}

[1] Afolayan, A., et al. (2015). Information Technology Usage in SMEs in a Developing Economy. Strategic Change, vol. 24, issue 5, pp. 483-498.

[2] Agus, A. (2015). Supply Chain Management: The Influence of SCM on Production Performance and Product Quality. Journal of Economics, Business and Management, vol. 3, issue 11, pp. 1046-1053.

[3] Amat, M. and Ishak, S. (2019). Faktor PSiKKIT: Pendorong Inovasi Pembungkusan Dalam Kalangan Industri Kecil Dan Sederhana Berasaskan Perusahaan Makanan. Geografia: Malaysian Journal of Society and Space, vol 15, issue 3, pp. 90-103.

[4] Ariani, D. and Dwiyanto, B. M. (2013). Analisis Pengaruh Supply Chain Management Terhadap Kinerja Perusahaan. Diponegoro Journal of Management, vol. 2, issue 3, pp. 1-10.

[5] Avisena, M. I. R. (November 2019). UMKM Didorong Kuasai Pasar Domestik. Retrieved on 20 August 2020 from https://mediaindonesia.com/ekonomi/270235/ umkm-didorong-kuasai-pasar-domestik

[6] Bouey, J. (2020). Assessment of COVID-19's Impact on Small and Medium-Sized Enterprises: Implications from China. Santa Monica, CA: RAND Corporation, 2020. https://www.rand.org/pubs/testimonies/CT524.html.

[7] Badan POM. (2020). Laporan Tahunan 2019. Retrieved on 12 September 2020 from https://pom.go.id/new/browse/more/laporan_tahunan/10-02-2020/10-02-2021/1

[8] BPOM RI. (2017). Peraturan Badan pengawas Obat dan Makanan Republik Indonesia. Badan Pengawas Obat Dan Makanan, vol. 2, issue 53, pp. 1689-1699.

[9] Brodjonegoro, B. P. (2020). UMKM 4.0. Kompas: Depok.

[10] Donthu, N. and Gustafsson, A. (2020). Effects of COVID-19 on Business and Research. Journal of Business Research, issue 117, pp. 284-289. vol 11.

[11] Hasnan, N. Z. N., et al. (2014). Food Factory Design: Reality and Challenges Faced by Malaysian SMEs. Agriculture and Agricultural Science Procedia, issue 2, vol 2, pp. 328- 336.

[12] Ibrahim, Z., Abdullah, F. and Ismail, A. (2016). International Business Competence and Small and Medium Enterprises. Procedia - Social and Behavioral Sciences, issue 224, vol 224, pp. 393-400. 
[13] Gatra, S. (2020, August). Petugas Medis Jakarta Belum Terima Intensif Sejak Maret 2020. Retrieved on 10 September from https://megapolitan.kompas.com/read/2020/ 08/19/20513351/petugas-medis-jakarta-belum-terima-insentif-sejak-maret-2020

[14] Kurniawan, A. and Kusumawardhani, A. (2017). Kinerja Umkm Batik Di Pekalongan. Diponegoro Journal of Management, issue 6, pp. 1-11.

[15] Kurnia, T. (2020, August). Diaspora Indonesia Rilis Buku Cerita COVID-19 dari 19 Negara. Retrieved on 10 September 2020 from https://www.liputan6.com/global/ $\mathrm{read} / 4337051 /$ diaspora-indonesia-rilis-buku-cerita-covid-19-dari-19-negara

[16] Martadisastra, D. S. (2017). Kinerja Pemasok Dalam Rantai Pasokan Makanan Kemasan: Suatu Kajian Kasus Di Indonesia. Jurnal Manajemen Bisnis vol. 12, issue 1, pp. 89-102.

[17] Maryati, T., Syarief, R. and Hasbullah, R. (2016). Analisis Faktor Kendala dalam Pengajuan Sertifikat Halal. (Studi Kasus: Pelaku Usaha Mikro, Kecil dan Menengah Makanan Beku di Jabodetabek). Jurnal Ilmu Produksi Dan Teknologi Hasil Peternakan, vol. 4, issue 3, pp. 364-371.

[18] Hami, N, et al. (2018). Sustainable Manufacturing Practices among SMEs in Malaysia. International Journal of Technology, vol. 9, issue 8, pp. 1658-1667.

[19] Qosasi, A., et al. (2019). The Impact of Information and Communication Technology Capability on the Competitive Advantage of Small Businesses. International Journal of Technology, vol. 10, issue 1, pp. 167-177.

[20] Raflis, A., Ishak, S. and Jusoh, M. A. (2020). The Impact of Covid-19 Movement Control Order on SMEs' Businesses and the Impact of Covid-19 Movement Control Order on SMEs' Businesses and Survival Strategies. Geografia: Malaysian Journal of Society and Space, vol. 6, issue 2, pp. 139-150.

[21] Rose, A.M.N. (2011). Lean Manufacturing Best Practices in SMEs. International Conference on Industrial Engineering and Operation Management, vol. 1, issue 1, pp. 872-877.

[22] Susmayanti, H. (2020, July). Data Terbaru Virus Corona di Jawa Timur, Surabaya Masih jadi Daerah dengan Penambahan Tertinggi. Retrieved on 10 August 2020 from https://jogja.tribunnews.com/2020/07/24/data-terbaru-virus-corona-dijawa-timur-surabaya-masih-jadi-daerah-dengan-penambahan-tertinggi

[23] Yulianti, M. D. and Resmi M. (2018). Tata Cara Registrasi Untuk Pangan Olahan Industri Rumah Tangga (Pirt) Dan Makanan Dalam Negeri (Md) Dalam Rangka Peningkatan Produk Yang Aman Dan Bermutu Di Bandung Jawa Barat. Farmaka, vol. 15, issue 3, pp. 57-64. 